\title{
Drug, Food, Chemical or Biomedical Material
}

National Cancer Institute

\section{Source}

National Cancer Institute. Drug, Food, Chemical or Biomedical Material. NCI Thesaurus. Code C1908.

An org anic or inorg anic substance, element, isotope, food or other materials derived from microorganism, plant, or animal sources. They can be used for the prevention, diagnosis, treatment or research of disease states, for industrial purposes, or for the promotion or maintenance of organism viability or health. 